\title{
Abbreviations of Peirce's Works and Archives
}

\section{Archives:}

R The Charles S. Peirce Papers, 1787-1951. Manuscripts in the Houghton Library of Harvard University, as identified by Richard Robin, Annotated Catalogue of the Papers of Charles S. Peirce, Amherst: University of Massachusetts Press, 1967, and in "The Peirce Papers: A Supplementary Catalogue”, Transactions of the Charles S. Peirce Society 7, 1971, pp.37-57. Peirce's manuscripts and letters are available, in part, in The Charles $S$. Peirce Papers, Microfilm Edition, Thirty Reels with Two Supplementary Reels Later Added. Cambridge: Harvard University Library Photographic Service, $1966 .^{1}$

HUA Harvard University Archives. Pusey Library, Harvard University.

WJP The William James Papers. Houghton Library, Harvard University.

CLF Christine Ladd Franklin and Fabian Franklin Papers. Butler Library, Rare Books and Manuscripts Collection, Columbia University.

VW Lady Victoria Alexandrina Maria Louisa Welby fonds, York University Archives and Special Collections.

\section{Edited Collections:}

SiL Studies in Logic, by Members of the Johns Hopkins University. Edited by Charles S. Peirce, Boston: Little, Brown, and Company, 1883. Reissued as a facsimile reprint in Foundations of Semiotics, Volume 1, with introductory essays by Achim Eschbach and Max H. Fisch. Amsterdam: John Benjamins, 1983.

DPP Dictionary of Philosophy and Psychology. Three volumes. Edited by James Mark Baldwin, 1901-1902. New York \& London: The Macmillan Company.

CLL Chance, Love and Logic: Philosophical Essays. Edited by Morris Cohen, with a supplementary essay on the pragmatism of Peirce by John Dewey. London: Kegan Paul, 1923.

CP The Collected Papers of Charles S. Peirce, 8 volumes. Edited by Charles Hartshorne, Paul Weiss and Arthur W. Burks. Cambridge: Harvard University Press, 1931-1958. Referred to by volume and paragraph number.

\footnotetext{
1 The microfilm edition is electronically available at https://rs.cms.hu-berlin.de/peircearchive/ Most manuscript and typescript sheets, notebooks and other material from the Harvard Peirce Papers are included in this microfilm edition, but only a minor part of letters and correspondence was included.
} 
PWP The Philosophy of Peirce: Selected Writings. Edited by Justus Buchler. New York: Harcourt, Brace and Company, 1940. Reissued as Philosophical Writings of Peirce, Dover, 1955.

CN Charles Sanders Peirce: Contributions to The Nation. Four volumes. Edited by Kenneth Laine Ketner and James Edward Cook. Lubbock, TX: Texas Technological University Press, 1975-1987.

NEM The New Elements of Mathematics by Charles S. Peirce. Four volumes. Edited by Carolyn Eisele. The Hague: Mouton De Gruyter, 1976.

SS Semiotic and Significs: The Correspondence between C.S. Peirce and Victoria Lady Welby. Edited by Charles S. Hardwick with the assistance of James Cook. Bloomington and Indianapolis, IN: Indiana University Press, 1977.

P A Comprehensive Bibliography and Index of the Published Works of Charles Sanders Peirce, with a Bibliography of Secondary Studies. Ketner, Kenneth Laine et al., (eds.). Greenwich: Johnson Associates, 1977. Second edition, A Comprehensive Bibliography of the Published Works of Charles Sanders Peirce, Bowling Green, OH: Philosophy Documentation Center, 1986.

W Writings of Charles S. Peirce: A Chronological Edition. Seven volumes. Edited by Max H. Fisch, C. J.W. Kloesel, et al. and the Peirce Edition Project. Bloomington and Indianapolis, IN: Indiana University Press, 19822009.

WMS Manuscripts as cataloged by the Peirce Edition Project, in W.

PLZ Charles S. Peirce: Phänomen und Logik der Zeichen. Helmut Pape (ed.). Frankfurt am Main: Suhrkamp, 1983.

HP Historical Perspectives on Peirce's Logic of Science: A History of Science. Two volumes. Edited by Carolyn Eisele. Berlin, New York and Amsterdam: Mouton De Gruyter, 1985.

RLT Reasoning and the Logic of Things: The Cambridge Conference Lectures of 1898. Edited by Kenneth Laine Ketner. Cambridge, Mass.: Harvard University Press, 1992.

EP 1 The Essential Peirce: Selected Philosophical Writings. Volume 1 (18671893). Edited by Nathan Houser and Christian J. W. Kloesel. Bloomington and Indianapolis, IN: Indiana University Press, 1992.

PPM Pragmatism as a Principle and Method of Right Thinking: The 1903 Harvard "Lectures on Pragmatism". Edited by Patricia Ann Turrisi. Albany, NY: State University of New York Press, 1997.

EP 2 The Essential Peirce: Selected Philosophical Writings. Volume 2 (18931913). Edited by the Peirce Edition Project. Bloomington and Indianapolis, IN: Indiana University Press, 1998. 
LoI Charles S. Peirce: The Logic of Interdisciplinarity. The Monist Series. Edited by Elize Bisanz. Berlin: Akademie Verlag, 2009.

PoM Philosophy of Mathematics: Selected Writings. Edited by Matthew E. Moore. Bloomington and Indianapolis, IN: Indiana University Press, 2010.

ILoS Illustrations of the Logic of Science, by Charles Sanders Peirce. Edited by Cornelis de Waal. Chicago: Open Court, 2014.

PSR Charles S. Peirce: Prolegomena to a Science of Reasoning. Phaneroscopy, Semeiotic, Logic. Edited by Elize Bisanz. Frankfurt am Main: Peter Lang, 2016.

LoF Charles S. Peirce: Logic of the Future. Writings on Existential Graphs. Edited by Ahti-Veikko Pietarinen. Volume 1: History and Applications, 2019. Volume 2/1: The Logical Tracts, 2021. Volume 2/2: The 1903 Lowell Lectures, 2021. Volume 3: Pragmaticism and Correspondence, 2021. Berlin and Boston: Mouton De Gruyter. 
